\title{
Aquatic insect community structure under the influence of small dams in a stream of the Mogi-Guaçu river basin, state of São Paulo
}

\author{
Saulino, HHL. ${ }^{a *}$, Corbi, JJ. ${ }^{b}$ and Trivinho-Strixino, S. ${ }^{c}$ \\ aPrograma de Pós Graduação em Ecologia e Recursos Naturais - PPGERN, Universidade Federal de São Carlos - UFSCar, \\ Rodovia Washington Luís, km 235, SP-310, CEP 13565-905, São Carlos, SP, Brazil \\ bDepartamento de Hidráulica e Saneamento, Escola de Engenharia de São Carlos - EESC, Universidade de São Paulo - USP, \\ Av. Trabalhador Sãocarlense, 400, CP 359, CEP 13566-590, São Carlos, SP, Brazil \\ 'Laboratório de Ecologia de Insetos Aquáticos, Departamento de Hidrobiologia, Universidade Federal de São Carlos - UFSCar, \\ Rodovia Washington Luís, km 235, SP-310, CEP 13565-905, São Carlos, SP, Brazil \\ *e-mail: hugosaulino@gmail.com
}

Received: August 21, 2012 - Accepted: January 22, 2013 - Distributed: February 28, 2014

(With 4 figures)

\begin{abstract}
The fragmentation of lotic systems caused by construction of dams has modified many aquatic communities. The objective of this study was to analyse changes in the aquatic insect community structure by discontinuity of habitat created by dams along the Ribeirão das Anhumas, a sub-basin of the Mogi-Guaçu River (state of São Paulo, Brazil). Entomofauna collection was carried out in 10 segments upstream and downstream of five dams along the longitudinal profile of the stream, with a quick sampling method using a D net (mesh $250 \mathrm{~mm}$ ) with 2 minutes of sampling effort. The insects were sorted and identified to the lowest possible taxonomic level and analysed by the Shannon diversity index, $\beta$ diversity, richness estimated by rarefaction curves and relative participation of functional feeding groups. The results showed a slight reduction in diversity in the downstream segments, as well as along the longitudinal profile of the stream. However, there were no significant differences in abundance and richness between the upstream and downstream segments, indicating that the dams did not influence these variables. Differences were observed in the functional feeding groups along the longitudinal profile. Predator and gatherer insects were dominant in all segments analysed. The feeding group of shredders was more abundant in the segment DSIII with the participation of Marilia Müller (Odontoceridae - Trichoptera), although we observed a decrease of shredders and scrapers with the decrease of the canopy cover reducing values of $\beta$ diversity in the continuum of Ribeirão das Anhumas. This result demonstrated the importance of the conservation of the riparian vegetation in order to maintain the integrity of the stream.
\end{abstract}

Keywords: aquatic macrofauna, riparian vegetation, habitat discontinuity, reservoir.

\section{Estrutura da comunidade de insetos aquáticos sob influência de pequenas represas em um ribeirão da bacia do Rio Mogi-Guaçu, Estado de São Paulo}

\begin{abstract}
Resumo
A fragmentação de sistemas lóticos causadas pela construção de represas tem causado modificação na estrutura das comunidades aquáticas. O objetivo deste estudo foi analisar as mudanças na estrutura da comunidade de insetos aquáticos decorrentes da descontinuidade de habitat criada por represamentos ao longo do Ribeirão das Anhumas, uma sub-bacia do rio Mogi-Guaçu (Estado de São Paulo, Brasil). A coleta da entomofauna foi realizada em 10 segmentos à montante e à jusante de cinco represas ao longo do perfil longitudinal do ribeirão, pelo método de varredura com rede D (malha $250 \mathrm{~mm}$ ) e esforço amostral de 2 minutos. Os insetos foram triados e identificados até o menor nível taxonômico possível e os diferentes grupos foram analisados pelo índice de diversidade de Shannon, diversidade $\beta$, riqueza estimada pela curva de rarefação e participação relativa dos grupos funcionais de alimentação. Os resultados apontaram ligeira redução na diversidade nos trechos à jusante, bem como ao longo do perfil longitudinal do ribeirão. Todavia, não houve diferenças significativas na abundância e riqueza entre os segmentos à montante e à jusante das represas, indicando que os represamentos não influenciaram nessas variáveis. Os resultados apontaram diferenças nos grupos funcionais de alimentação ao longo do perfil longitudinal. Os insetos predadores e coletores foram os grupos de alimentação predominantes em todos os segmentos analisados. O grupo dos insetos fragmentadores foi mais abudante no segmento DSIII com a participação de Marilia Müller (Odontoceridae- Trichoptera), embora observado um decréscimo de fragmentadores e rapaspadores com a redução da cobertura vegetal, reduzindo os valores dediversidade b no perfil longitudinal do Ribeirão das Anhumas. Os resultados demonstraram a importancia da conservação da vegetação ripária para a manutenção da integridade do ribeirão.
\end{abstract}

Palavras-chave: macrofauna aquática, vegetação ripária, descontinuidade de habitat, represa. 


\section{Introduction}

The fragmentation of lotic systems due to dam construction causes impacts on aquatic animals that depend on the waterflow for dispersion. The isolation of communities in sites both upstream and downstream of dams, results over time, in the extinction of local populations, preventing the natural re-colonisation of the communities (Merrill et al., 2001).

With the development of knowledge in hydrology, many activities have been conducted in the rivers for economic purposes, such as construction of large dams and of courses for navigation. These factors have been responsible for many changes in aquatic ecosystems (Rodrigues, 2009). According to Johnson et al. (2001), there has been a worldwide increase in the number of large dams since the 1950 s, turning lotic systems into lentic ones, causing extensive loss of habitat and fragmenting around $60 \%$ of watersheds, while still maintaining a flow of water. At the same time, many small reservoirs have been built along small rivers or streams for the most diverse purposes (irrigation, aquaculture, recreation and livestock).

Aquatic insects, the richest and most abundant in aquatic communities, may also be affected by the impoundment of rivers and streams. The distribution of this group in these environments is directly related to food availability, substrate type, and physical and chemical characteristics of water (Callisto et al., 2005), but little is known about the interference of habitat fragmentation caused by dams in this community (Monaghan et al., 2005). In view of this question, the objective of this study was to analyse changes in the aquatic insect community structure resulting from the disruption of habitats caused by small dams constructed along a stream of the Mogi-Guaçu sub-basin, in the state of São Paulo (Brazil).

\section{Study Area}

Ribeirão Anhumas is a little river located in the midwest of the state of São Paulo belonging to the watershed of Mogi Guaçu River. This stream, with a drainage basin of $14,653 \mathrm{~km}^{2}$ (Santos, 1999), runs through nearly $30 \mathrm{~km}$ between coordinates $21^{\circ} 86^{\prime} \mathrm{S}, 47^{\circ} 98^{\prime} \mathrm{W}$ and $21^{\circ} 62^{\prime} \mathrm{S}$, $47^{\circ} 98^{\prime} \mathrm{W}$, and flows into the Ribeirão das Cabaceiras. The vegetation of the Ribeirão das Anhumas is composed of stretches of preserved riparian vegetation, savanna forest and semi-deciduous forest. Along its longitudinal profile, there are five dams ranging from 300 to 3000 metres in length used for various activities such as agricultural irrigation, recreational activities (fishing and boating) and collection of water for human consumption.

\section{Material and Methods}

\subsection{Aquatic fauna}

The study was carried out in 10 segments of the Ribeirão das Anhumas (five upstream - US and five downstream - DS) in stretches with 50 metres upstream and downstream of each dam (see Figure 1), by the quick sampling method using a D net (mesh of $250 \mathrm{~mm}$ ), with sampling effort of two minutes. In each segment three samples were collected. The specimens were sorted and identified to the lowest possible taxonomic level, using the following identification keys: Trivinho-Strixino (2011), Pepinelli (2011), Domínguez and Fernández (2009), Domínguez et al. (2006), Pes et al. (2005), Costa et al. (2000), Nieser and Melo (1997), Lecci and Fröehlich (2007).

The main physical and chemical variables (dissolved oxygen, temperature, $\mathrm{pH}$ and electric conductivity) were determined in the field using the Horiba multisensor (model U10), followed by the environmental characterization of the segments sampled, as in the Protocol of Environmental Characterisation Biota / FAPESP (Suriano, 2008). The superficial flow speed was estimated by the float method (see Table 1).

\subsection{Data analysis}

The aquatic insect community was analysed for numerical and relative contribution of each taxon in the stream segments using the Shannon diversity index, the Pielou evenness and dominance index. Student's $t$-test was used to verify significant differences in community abundance and richness between the stream segments. The richness was estimated by the method of rarefaction computed by the Monte Carlo method (Hulbert, 1971; Bispo and Oliveira 2007) using the lowest abundance (150 individuals). The $\beta$ diversity between each two successive segments, and also between forested and non forested stretches, was evaluated using the dissimilarity index, with the statistical software STATISTICA (version 5.1). The logarithms converted abundances $[\log (x+1)]$ were used to calculate a similarity matrix among the segments using the Morisita index. The clustering was measured by UPGMA and distortions generated were evaluated by the Cophenetic Correlation index. The taxa were grouped into functional feeding categories according to the classification of Merritt and Cummins (1996), and supplemented by regional studies of Chironomidae larvae (Trivinho-Strixino and Strixino, 1998; Janke and TrivinhoStrixino, 2007); in the comparative analysis, the relative participation of each guild was considered. The following feeding categories were considered: predators, scrapers, shredders and collectors. A PCA analysis was used to verify if there were differences in insect feeding categories in the upstream and downstream segments of the stream.

\section{Results}

The main environmental characteristics of the Ribeirão das Anhumas are shown in Table 1. The total number of insects collected in the 10 segments and their respective functional feeding categories is presented in Tables 2, 3 and 4. In total, 2498 insect specimens in 92 taxa, distributed in 40 families were analysed. Chironomidae was the most abundant and diverse family in all segments studied, representing approximately $60 \%$ of individuals and $36 \%$ of insect genera. Polypedilum (with $14.0 \%$ ) was the most representative taxon of the community, being present in almost all segments of the stream. Pentaneura, 


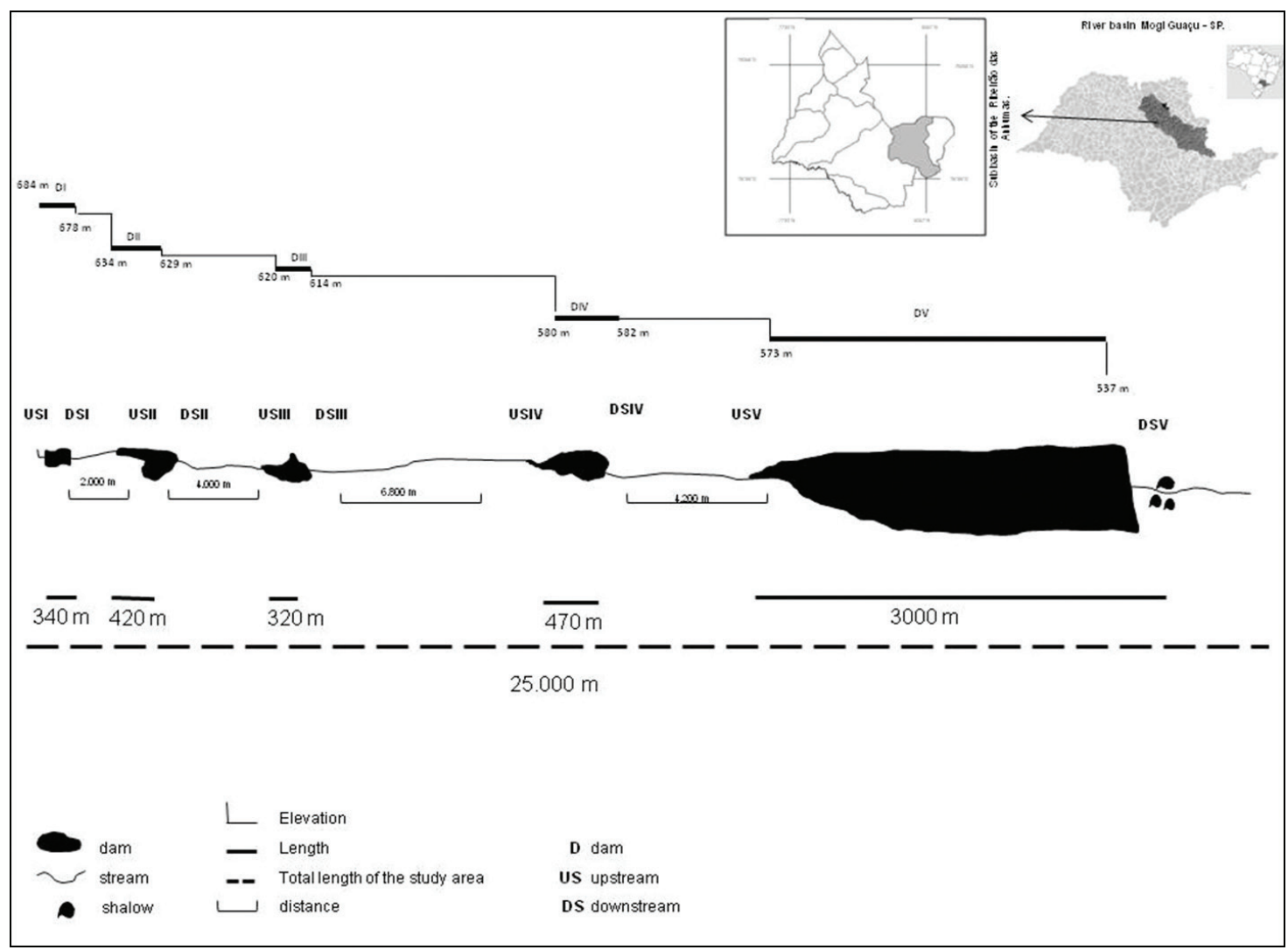

Figure 1. Geographic location of the hydrographic basin of Ribeirão das Anhumas (central region of São Paulo state) and schematic representation of the longitudinal profile with indication of the dams and segments studied. (D) - dam, (US) upstream, (DS) - downstream.

Table 1. Environmental characterization of the segments upstream and downstream of five dams along the longitudinal profile of the Ribeirão das Anhumas (São Paulo, Brazil).

\begin{tabular}{|c|c|c|c|c|c|c|c|c|c|c|}
\hline & \multicolumn{10}{|c|}{ Segment } \\
\hline & \multicolumn{2}{|c|}{ DI } & \multicolumn{2}{|c|}{ DII } & \multicolumn{2}{|c|}{ DIII } & \multicolumn{2}{|c|}{ DIV } & \multicolumn{2}{|c|}{ DV } \\
\hline & USI & DSI & USII & DSII & USIII & DSIII & USIV & DSIV & USV & DSV \\
\hline Canopy & \multicolumn{2}{|c|}{ Closed } & \multicolumn{2}{|c|}{ Closed } & \multicolumn{2}{|c|}{ Half } & \multicolumn{2}{|c|}{ Absent } & \multicolumn{2}{|c|}{ Absent } \\
\hline Cond. $\left(\mu \mathrm{S} . \mathrm{cm}^{-1}\right)$ & 0.1 & 0.1 & 0.3 & 0.2 & 0.2 & 0.2 & 0.3 & 0.3 & 0.3 & 0.3 \\
\hline D.O. (mg.L $\left.\mathrm{L}^{-1}\right)$ & 4.87 & 8.47 & 7.63 & 9.00 & 6.8 & 8.43 & 5.33 & 5.97 & 8.07 & 8.75 \\
\hline $\mathrm{pH}$ & 5.62 & 5.94 & 6.03 & 6.32 & 5.8 & 5.65 & 6.37 & 6.83 & 6.53 & 6.53 \\
\hline water temperature $\left({ }^{\circ} \mathrm{C}\right)$ & 16.7 & 17.8 & 19.3 & 19.1 & 20.0 & 19.0 & 17.7 & 19.0 & 17.0 & 20.01 \\
\hline width (m) & 0.94 & 1.00 & 1.00 & 3.00 & 2.4 & 5.77 & 7.00 & 5.67 & 3.83 & 5.67 \\
\hline Current velocity $\left(\mathrm{cm} . \mathrm{s}^{-1}\right)$ & 5 & 4 & 4 & 3 & 5 & 7 & 7 & 6 & 4 & 4 \\
\hline depth (m) & 0.18 & 0.25 & 0.16 & 0.27 & 0.26 & 0.50 & 1.21 & 1.24 & 0.80 & 0.42 \\
\hline
\end{tabular}

(D) - dam, (US) - upstream, (DS) - downstream.

Ablabesmyia and Larsia (Chironomidae) were also representative, contributing respectively with 7.8\%, 5.0\% and $5.0 \%$ of the total entomofauna. Student's $t$-test showed no significant differences between the segments sampled ( $p>0.05)$, indicating no apparent interference of habitat disruption in the aquatic insect community. The cluster analysis showed differences in insect fauna between the segments, delimiting three groups: one gathering in the stretches near the headwaters of the stream (USI-DSII), another in the intermediate section (USIII-DSIII) and the last found in the posterior segments of the stream (USIV-DSV) (see Figure 2). A small reduction in the Shannon diversity (as shown in Table 5) was observed, as well as in the richness in the segments downstream of the dams. The $\beta$ diversity index showed the highest values in first upstream and downstream segments (USI to USIII) indicating low similarity between these forested portions of stream. The remaining segments (DSIII to DSV) showed 
Table 2. Number of specimens and functional feeding categories for Odonata, Ephemeroptera and Hemiptera taxa in upstream and downstream segments of the five dams in the Ribeirão das Anhumas. (FFC) functional feeding categories; (C) collectors; (Sh) shredders; (Sc) scrapers; (Pr) predators. (D) - dam, (US) - upstream, (DS) - downstream.

\begin{tabular}{|c|c|c|c|c|c|c|c|c|c|c|c|c|}
\hline \multirow{3}{*}{ Genus } & \multirow{3}{*}{ FFC } & \multicolumn{10}{|c|}{ Segment } & \multirow{3}{*}{ Total } \\
\hline & & \multicolumn{2}{|c|}{ DI } & \multicolumn{2}{|c|}{ DII } & \multicolumn{2}{|c|}{ DIII } & \multicolumn{2}{|c|}{ DIV } & \multicolumn{2}{|c|}{ DV } & \\
\hline & & USI & DSI & USII & DSII & USIII & DSIII & USIV & DSIV & USV & DSV & \\
\hline \multicolumn{13}{|l|}{ Odonata } \\
\hline Limnetron Förster & $\operatorname{Pr}$ & 1 & - & - & - & - & - & - & 3 & - & - & 4 \\
\hline Argia Rambur & $\operatorname{Pr}$ & 2 & 1 & 1 & - & - & - & - & - & - & - & 4 \\
\hline Archeogomphus Williamson & $\operatorname{Pr}$ & 8 & - & 7 & 2 & 1 & - & 1 & - & - & 1 & 20 \\
\hline Hetaerina Hagen & $\operatorname{Pr}$ & 2 & 6 & 1 & 1 & 1 & - & 1 & 35 & 2 & 3 & 52 \\
\hline Heliocharis Selys & $\operatorname{Pr}$ & - & - & 9 & 3 & - & - & - & - & - & - & 12 \\
\hline Epipleoneura William & $\operatorname{Pr}$ & - & - & - & - & - & 1 & - & - & - & - & 1 \\
\hline Idioneura Sekys & $\operatorname{Pr}$ & - & - & - & - & - & - & - & 1 & 2 & 6 & 9 \\
\hline Neoneura Selys & $\operatorname{Pr}$ & - & - & - & - & 3 & - & 12 & 38 & - & - & 53 \\
\hline Cannaphila Kirby & $\operatorname{Pr}$ & 20 & - & - & - & - & - & 1 & - & - & - & 21 \\
\hline Libellula Linnaeus & $\operatorname{Pr}$ & 17 & 1 & 3 & 1 & - & - & 7 & 23 & 12 & 11 & 75 \\
\hline Orthemis Hagen & $\operatorname{Pr}$ & - & - & - & 20 & 1 & - & 3 & - & - & - & 24 \\
\hline Ephemeroptera & & & & & & & & & & & & 0 \\
\hline Caenis Stephens & $\mathrm{Co}$ & 1 & - & - & - & 4 & - & 15 & 10 & - & - & 30 \\
\hline Miroculis Edmundis & $\mathrm{Co}$ & 20 & - & - & - & - & - & - & - & - & 7 & 27 \\
\hline Paracleodes Day & Co & - & - & - & - & - & - & 10 & - & 7 & - & 17 \\
\hline Hemiptera & & & & & & & & & & & & 0 \\
\hline Tenagobia Bergroth & $\mathrm{Sc}$ & - & 1 & - & - & - & - & - & - & - & 16 & 17 \\
\hline Paravelia Polhemus & $\operatorname{Pr}$ & - & - & - & - & - & - & - & - & - & 1 & 1 \\
\hline Rhagovelia Mayr & $\operatorname{Pr}$ & 2 & - & 1 & - & - & - & - & - & 2 & - & 5 \\
\hline Brachymetra Mayr & $\operatorname{Pr}$ & 1 & - & 1 & - & - & - & - & - & - & - & 2 \\
\hline Charmatometra Kirkaldy & $\operatorname{Pr}$ & - & - & 3 & 1 & - & - & - & - & - & - & 4 \\
\hline Curicta Stål & $\operatorname{Pr}$ & - & 1 & - & 2 & - & - & - & - & - & - & 3 \\
\hline Ranatra Fabricius & $\operatorname{Pr}$ & - & 1 & - & - & - & - & - & - & - & - & 1 \\
\hline Mesovelia Mulsant \& Rey & $\operatorname{Pr}$ & - & - & 2 & - & - & - & - & - & - & - & 2 \\
\hline Neoplea Esaki \& China & $\operatorname{Pr}$ & - & - & - & - & - & - & - & 3 & - & - & 3 \\
\hline Abedus Say & $\operatorname{Pr}$ & 1 & - & - & 1 & - & - & - & 2 & - & - & 4 \\
\hline Belostoma Laitrelle & $\operatorname{Pr}$ & 1 & - & - & 2 & 1 & - & - & 4 & - & - & 8 \\
\hline Horvathinia Montandon & $\operatorname{Pr}$ & 1 & - & - & 1 & - & - & - & - & - & - & 2 \\
\hline \multirow[t]{2}{*}{ Weberiella De Carlo } & $\operatorname{Pr}$ & - & 11 & 1 & 2 & - & - & - & - & - & - & 14 \\
\hline & & 77 & 22 & 29 & 36 & 11 & 1 & 50 & 119 & 25 & 45 & 415 \\
\hline
\end{tabular}

low $\beta$ diversity, indicating great similarity in the insect communities of this section (see Figure 3 ). The $\beta$ diversity when comparing forested and non-forested stretches also indicated low values in non-forested stretches, respectively 9.04 and 1.74 .

The analysis of functional feeding categories indicated predominance of predators and collectors in all segments analysed (as shown in Table 5). The PCA analysis also delimited the first upstream segments (USI, USII and USIII) (see Figure 4) where the participation of shredders and scrapers was more representative, in the other segments these guilds were reduced or absent.

\section{Discussion}

The Serial Discontinuity Concept (SDC) created by Ward and Stanford (1983), has served as a basis for studying the interference of the construction of dams in aquatic invertebrate communities. This study highlights the changes caused by dams on biotic communities such as the reduction in abundance or even the elimination of some species, while others may arise or increase their abundance after stabilization of the flow in the river bed. The wildlife that inhabits the stretches downstream of these impoundments has to adapt to new environmental conditions (Ward and Stanford, 1979; Pardo et al., 1998). In studies that analysed the changes resulting from the construction of small dams on the community of aquatic invertebrates, significant differences in richness and Shannon diversity were commonly not found (Chessman et al., 1987; Maroneze et al., 2011). However, after the construction of spillways, significant differences in abundance and differences in the functional feeding group structure, with the replacement of filter-collectors by gathering-collectors were observed (Maroneze et al., 2011). It can be inferred 
Table 3. Number of specimens and functional feeding categories of Trichoptera, Plecoptera, Coleoptera and Lepidoptera taxa in upstream and downstream segments of the five dams in the Ribeirão das Anhumas. (Legends as in Table 2).

\begin{tabular}{|c|c|c|c|c|c|c|c|c|c|c|c|c|}
\hline \multirow{3}{*}{ Gênero } & \multirow{3}{*}{ FFC } & \multicolumn{10}{|c|}{ Segment } & \multirow{3}{*}{ Total } \\
\hline & & \multicolumn{2}{|c|}{ DI } & \multicolumn{2}{|c|}{ DII } & \multicolumn{2}{|c|}{ DIII } & \multicolumn{2}{|c|}{ DIV } & \multicolumn{2}{|c|}{ DV } & \\
\hline & & USI & DSI & USII & DSII & USIII & DSIII & USIV & DSIV & USV & DSV & \\
\hline \multicolumn{13}{|l|}{ Trichoptera } \\
\hline Macronema Pictet & Co & - & 1 & 19 & 4 & - & - & - & - & - & 1 & 25 \\
\hline Macrostemum Kolenati & $\mathrm{Co}$ & - & - & - & - & 18 & 45 & - & - & 3 & 7 & 73 \\
\hline Marilia Müller & $\mathrm{Sh}$ & 5 & 3 & 1 & 12 & 22 & 1 & 2 & 1 & - & - & 47 \\
\hline Alterosa Blahnik & Co & 1 & - & - & - & - & - & 1 & 7 & - & - & 9 \\
\hline Chimarra Stephens & $\mathrm{Co}$ & - & - & - & - & - & - & - & 1 & - & - & 1 \\
\hline Mortoniella Ulmer & Sh & 5 & 1 & - & - & - & - & - & - & - & - & 6 \\
\hline Philloicus Müller & Sh & - & 3 & - & - & - & - & - & - & - & - & 3 \\
\hline Grumicha Müller & Co & - & - & 1 & - & 9 & 1 & - & - & - & - & 11 \\
\hline Cynerllus Banks & $\mathrm{Co}$ & - & - & 1 & - & - & 17 & 7 & - & 3 & 3 & 31 \\
\hline Cernotina Ross & $\mathrm{Co}$ & - & - & - & - & - & 7 & 8 & 3 & 1 & 3 & 22 \\
\hline Nectopsyche Müller & $\mathrm{Sh}$ & - & - & - & 1 & - & - & - & - & - & - & 1 \\
\hline Oecetis McLachlan & $\mathrm{Sh}$ & - & - & - & - & - & - & - & 1 & 3 & - & 4 \\
\hline Triplectides Kolenati & $\mathrm{Sh}$ & - & - & 6 & 1 & 4 & - & - & - & - & - & 11 \\
\hline Hydroptila Dalman & $\mathrm{Sc}$ & - & - & - & - & - & - & - & 2 & 19 & - & 21 \\
\hline \multicolumn{13}{|l|}{ Plecoptera } \\
\hline Kempnyia Klapálek & $\operatorname{Pr}$ & 1 & - & 2 & - & 2 & 10 & - & - & - & - & 15 \\
\hline \multicolumn{13}{|l|}{ Coleoptera } \\
\hline Gyretes Brullé & $\operatorname{Pr}$ & 7 & 19 & - & 17 & - & - & - & 2 & - & - & 45 \\
\hline Dryops Olivier & $\operatorname{Pr}$ & 1 & - & 3 & 2 & - & - & - & - & - & - & 6 \\
\hline Anticura Spangler & $\operatorname{Pr}$ & - & 6 & - & - & - & - & - & - & - & - & 6 \\
\hline Hydrocanthus Say & $\operatorname{Pr}$ & - & 17 & - & - & - & - & - & - & 1 & - & 18 \\
\hline Bidessonotus Régimbart, & $\operatorname{Pr}$ & - & - & - & 1 & - & - & - & 3 & - & - & 4 \\
\hline Copelatus Erichson & $\operatorname{Pr}$ & 2 & - & - & 1 & - & - & - & - & - & - & 3 \\
\hline Derovatellus Sharp & $\operatorname{Pr}$ & - & - & - & 1 & - & - & - & - & - & - & 1 \\
\hline Hydrovatus Motschulsky & $\operatorname{Pr}$ & - & - & 1 & - & - & - & - & - & 1 & - & 2 \\
\hline Notaticus Zimemrman & $\operatorname{Pr}$ & - & - & - & - & - & - & - & 1 & - & - & 1 \\
\hline Ranthus Lac & $\operatorname{Pr}$ & - & - & 1 & - & - & - & - & - & - & - & 1 \\
\hline Austrolimnus Carter \& Zeck & $\mathrm{Sc}$ & - & - & 2 & 4 & - & 1 & - & - & - & - & 7 \\
\hline Heterelmis Sharp & $\mathrm{Sc}$ & - & 3 & 6 & 1 & - & 1 & - & - & - & - & 11 \\
\hline Microcylloepus Hinton & $\mathrm{Sc}$ & - & - & 2 & 5 & - & 1 & - & - & - & - & 8 \\
\hline Stegoelmis Hinton & $\mathrm{Sc}$ & - & - & - & - & 1 & 1 & - & - & - & - & 2 \\
\hline Xenelmis Hinton & $\mathrm{Sc}$ & - & - & 1 & - & 3 & - & - & - & - & - & 4 \\
\hline \multicolumn{13}{|l|}{ Lepidoptera } \\
\hline Parapoynx Guenée & Sh & - & - & - & - & - & - & 3 & - & - & - & 3 \\
\hline \multirow[t]{2}{*}{ Synclita Lederer } & Sh & - & 1 & - & - & - & - & - & - & - & - & 1 \\
\hline & & 22 & 54 & 46 & 50 & 59 & 85 & 21 & 21 & 31 & 14 & 403 \\
\hline
\end{tabular}

that the discontinuity of small dams in the Ribeirão das Anhumas did not have an impact on the aquatic insect fauna, as the results were similar to the studies mentioned above. However, the environmental characteristics of the surrounding segments as well as the hydrological channel of the stream were important factors influencing the community composition of aquatic insects in the continuum of Ribeirão das Anhumas.

According to Heino (2009), the structure of aquatic insect communities changes in a spatial scale according to the substrate modification. Consequently, the substrate provided by the riparian vegetation (leaf, wood) proved to be the environmental factor that most influenced in the diversity of insects (Bispo et al., 2002; Song et al., 2009). The dense cover vegetation in segments USI, DSI, USII and DSII certainly contributes to more environmental heterogeneity in these areas, favoring a highest richness, Shannon index and $\beta$ diversity in the continuum. Streams with high input of larger organic particles (leaves, branches, trunks and fruits), generally promote a great availability of niches, favoring the establishment of numerous species (Straka et al., 2012). 
Table 4. Number of specimens and functional feedings categories of Diptera in upstream and downstream segments of the five dams in the Ribeirão das Anhumas. (Legend as in Table 2).

\begin{tabular}{|c|c|c|c|c|c|c|c|c|c|c|c|c|}
\hline \multirow{3}{*}{ Genus } & \multirow{3}{*}{ FFC } & \multicolumn{10}{|c|}{ Segment } & \multirow{3}{*}{ Total } \\
\hline & & \multicolumn{2}{|c|}{ DI } & \multicolumn{2}{|c|}{ DII } & \multicolumn{2}{|c|}{ DIII } & \multicolumn{2}{|c|}{ DIV } & \multicolumn{2}{|c|}{ DV } & \\
\hline & & USI & DSI & USII & DSII & USIII & DSIII & USIV & DSIV & USV & DSV & \\
\hline Culicoides Latreille & $\operatorname{Pr}$ & 8 & 4 & 12 & 18 & - & - & 10 & - & - & 19 & 71 \\
\hline Simulium Latreille & Co & 3 & - & 3 & - & - & - & 2 & - & - & - & 8 \\
\hline Limnophila Alexander & $\operatorname{Pr}$ & 3 & - & 2 & 1 & - & - & - & - & - & - & 6 \\
\hline Tabanus Linnaeus & $\operatorname{Pr}$ & - & - & - & 1 & - & - & - & - & - & 1 & 2 \\
\hline Asheum Sublette \& Sublette & Co & - & - & 1 & 1 & - & - & - & - & - & 12 & 14 \\
\hline Beardius Reiss \& Sublette & Co & - & - & - & - & 5 & - & 6 & 1 & - & - & 12 \\
\hline Cladopelma Kieffer & Co & - & - & - & - & - & - & 1 & - & - & - & 1 \\
\hline Chironomus Meigen & Co & 7 & 11 & - & 3 & - & - & 3 & 8 & 1 & 88 & 121 \\
\hline $\begin{array}{l}\text { Chironomus detritricola } \\
\text { Correia \& Trivinho-Strixino }\end{array}$ & Co & 42 & - & - & - & - & - & - & - & - & - & 42 \\
\hline Cryptochironomus Kieffer & Co & - & - & - & - & 1 & - & 1 & 3 & - & 1 & 6 \\
\hline Endotribelos Grodhaus & Sh & 25 & - & 2 & - & 5 & - & 1 & - & 1 & - & 34 \\
\hline Endotribelos sp. 2 & Sh & - & - & 21 & 2 & 3 & 2 & 2 & - & - & - & 30 \\
\hline Goeldichironomus Fittkau & Co & - & 2 & - & 8 & - & - & - & - & - & - & 10 \\
\hline Parachironomus Lenz & Co & - & - & - & - & - & 28 & - & - & 1 & - & 29 \\
\hline Pelomus Reiss & Co & - & 1 & 12 & 12 & - & 2 & - & - & 1 & - & 28 \\
\hline Pelomus sp. 3 & Co & - & - & - & - & - & - & - & - & 4 & - & 4 \\
\hline Polypedilum Kieffer & Co & 18 & 2 & 32 & 50 & - & - & 152 & 83 & 14 & - & 351 \\
\hline Stenochironomus Kieffer & Sh & 5 & 1 & 10 & 1 & 2 & 3 & - & - & 1 & - & 23 \\
\hline Riethia Kieffer & Co & - & - & - & - & - & - & - & - & - & 1 & 1 \\
\hline Caladomyia Säwedall & Co & 2 & 9 & 2 & - & 2 & 4 & - & - & 2 & 2 & 23 \\
\hline $\begin{array}{l}\text { Rheotanytarsus Thienemann } \\
\& \text { Bause }\end{array}$ & Co & - & - & 1 & 3 & - & 2 & 1 & - & 2 & - & 9 \\
\hline Tanytarsus v. d. Wulp & $\mathrm{Co}$ & 2 & 2 & 10 & 3 & 2 & 4 & 5 & 3 & 12 & 12 & 55 \\
\hline $\begin{array}{l}\text { Tanytarsus caipira Trivinho- } \\
\text { Strixino \& Strixino }\end{array}$ & Co & 14 & 3 & 2 & 2 & - & - & - & - & 1 & - & 22 \\
\hline Corynoneura Winnertz & Co & - & - & 2 & - & - & - & - & - & - & - & 2 \\
\hline Cricotopus v. d. Wulp & Co & - & - & - & - & - & - & - & - & 2 & - & 2 \\
\hline $\begin{array}{l}\text { Gymnometriocnemus } \\
\text { Goetghebuer }\end{array}$ & Co & - & - & 1 & - & - & - & - & - & - & - & 1 \\
\hline Lopescladius Oliveira & Co & 4 & - & - & - & - & - & - & - & - & - & 4 \\
\hline Nanocladius Kieffer & Co & 1 & 6 & 1 & 1 & - & 1 & - & - & 2 & - & 12 \\
\hline $\begin{array}{l}\text { Onconeura Andersen and } \\
\text { Sæther }\end{array}$ & Co & 2 & - & 3 & 2 & - & - & 1 & - & - & - & 8 \\
\hline $\begin{array}{l}\text { Parametriocnemus } \\
\text { Goetghebuer }\end{array}$ & Co & 1 & - & - & - & - & - & - & - & - & - & 1 \\
\hline Paracladius Hirvenoja & Co & - & - & - & - & - & - & 26 & 1 & - & - & 27 \\
\hline Procladius Skuse & $\operatorname{Pr}$ & - & - & - & - & 9 & - & 1 & - & 2 & - & 12 \\
\hline Clinotanypus Kieffer & $\operatorname{Pr}$ & - & - & 1 & - & - & - & - & - & - & - & 1 \\
\hline Coelotanypus Kieffer & $\operatorname{Pr}$ & - & - & 1 & - & 40 & 1 & 22 & 13 & 5 & - & 82 \\
\hline $\begin{array}{l}\text { Denopelopia Roback \& } \\
\text { Rutter }\end{array}$ & $\operatorname{Pr}$ & - & - & - & - & - & - & - & 14 & - & - & 14 \\
\hline Djalmabaptista Fittkau & $\operatorname{Pr}$ & - & - & 4 & 3 & 3 & - & 8 & 5 & 59 & - & 82 \\
\hline Fittkaumyia Karunakaran & $\operatorname{Pr}$ & - & - & - & - & - & - & - & - & - & 1 & 1 \\
\hline $\begin{array}{l}\text { Guassutanypus Roque \& } \\
\text { Trivinho-Strixino }\end{array}$ & $\operatorname{Pr}$ & 27 & 1 & - & - & - & - & - & - & 7 & - & 35 \\
\hline Ablabemyia Johannsen & $\operatorname{Pr}$ & 5 & 1 & 4 & 3 & 1 & 6 & 28 & 30 & 30 & 22 & 130 \\
\hline gr. Thienemannimyia Fittkau & $\operatorname{Pr}$ & - & 4 & - & - & - & - & - & - & - & - & 4 \\
\hline Labrundinia Fittkau & $\operatorname{Pr}$ & - & 2 & 2 & - & - & 16 & - & - & - & - & 20 \\
\hline Larsia Fittkau & $\operatorname{Pr}$ & 4 & 72 & - & 16 & 7 & 15 & 21 & - & 1 & 1 & 137 \\
\hline Pentaneura Philippi & $\operatorname{Pr}$ & - & 2 & 28 & 82 & - & 49 & - & 4 & 15 & 15 & 195 \\
\hline & & 173 & 123 & 157 & 212 & 80 & 133 & 291 & 165 & 163 & 175 & 1672 \\
\hline
\end{tabular}


According to Vinson and Hawkins (1998), some hydraulic characteristics of the streams, such as increased water flow and decreased allochthonous input, as observed in the DSIII segment, can influence the reduction in quantity and quality of habitat. These variables changes, observed from segment DSIII, could explain the reduction of the Shannon and $\beta$ diversity values in the continuum. This segment is classified as third order, with bed substrate composed by sand and rock, a feature that should have influenced in the reduction of diversity and the cluster grouping, separating it from the two first forested segments. Unlike the faunal composition of the forested segments, the absence of riparian vegetation and increased channel width and depth of the segments USIV, DSIV, USV and DSV, promoted a more similar faunal composition (lowest $\beta$ diversity values), due to lower availability of niches and food resources.

The distribution of functional feeding groups in the longitudinal profile of the Ribeirão das Anhumas was similar to that obtained by Roque and Trivinho-Strixino

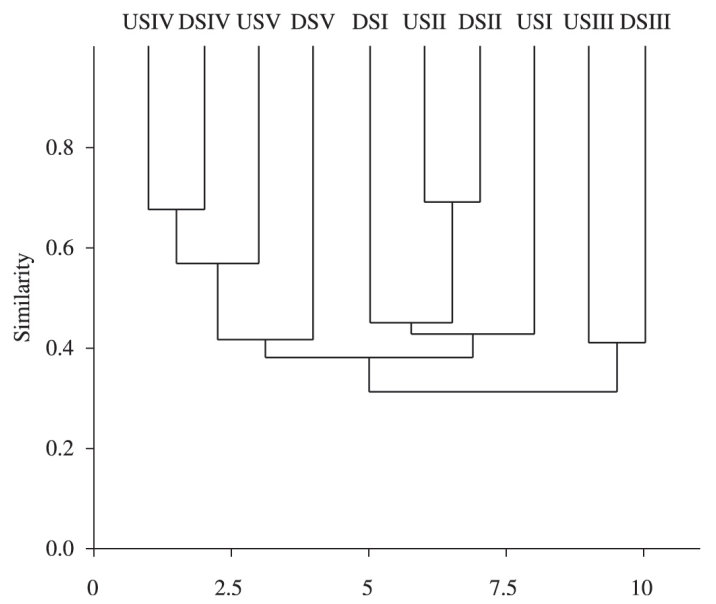

Figure 2. Dendrogram representing the similarity among insect fauna (Morisita, cophenetic correlation $=0.80$ ) collected in upstream and downstream segments of the five dams of the Ribeirão das Anhumas. (Legend as in Figure 1).
(2001) in the Fazzari stream (São Carlos - SP), which were also dominated by predators followed by gatheringcollectors. This may be related to low water velocity and accumulation of organic matter in areas of deposits in the stream beds, which allows the establishment of the predator group, facilitating the capture of prey. The ability to obtain and use fine organic matter as a food resource is a common behaviour of many larvae of Chironomidae (Berg, 1995). The availability of food resources is related to the continued rapid decomposition of leaf litter promoted by microbial activity in tropical streams (Dudgeon, 1982; Covich, 1988; Mathuriau and Chauvet, 2002; Dobson et al., 2003). Due to this increased availability of particulate organic matter (FPOM), many authors suggest that tropical streams have low participation of shredders (Dudgeon, 2000; Buss et al., 2002; Dobson et al., 2003), a fact also observed in this study. Although in the present study a decrease in abundance of some taxa with the decreasing cover vegetation was observed, the prevalence of some shredders and scrapers, as the chironomids larvae of Stenochironomus and Endotribelos and the Elmidae larvae (groups which are dependent of dead plant material as food resource and habitat), was noticed in the forested stretches (Borkent, 1984; Berg, 1995; Passos et al., 2003; Roque et al., 2005; Roque and Trivinho-Strixino, 2008; Corbi \& Trivinho Strixino, 2008). The largest relative contribution of this feeding category in the segment DSIII was related to the presence of larvae of Marilia and also by the presence of woody debris in the shore of this stream segment. These groups of insect were absent in the non-forested segments USIV, DSIV, USV and DSV, and also in the stretches with submerged aquatic macrophytes, a possible resource of food for shredders and scrapers. Nevertheless the greater heterogeneity promoted by macrophyte beds (Albertoni and Palma-Silva, 2006) resulted in a slight increase of the diversity in these segments. The decrease of $\beta$ diversity along the segments of Ribeirão das Anhumas was influenced by the reduction of these feeding groups. This result demonstrated the importance of the conservation of the riparian vegetation to maintain the integrity of the river.

Table 5. Main community characteristics of the aquatic insect in the upstream and downstream segments of the five dams in the Ribeirão das Anhumas. (Legend as in Table 1).

\begin{tabular}{lcccccccccc}
\hline & \multicolumn{10}{c}{ Segments } \\
\cline { 2 - 11 } & \multicolumn{3}{c}{ DI } & \multicolumn{1}{c}{ DII } & \multicolumn{2}{c}{ DIII } & \multicolumn{2}{c}{ DIV } & \multicolumn{2}{c}{ DV } \\
\cline { 2 - 11 } & USI & DSI & USII & DSII & USIII & DSIII & USIV & DSIV & USV & DSV \\
\hline Abundance & 272 & 199 & 232 & 298 & 150 & 219 & 362 & 305 & 219 & 234 \\
Taxa number & 38 & 32 & 46 & 42 & 25 & 24 & 31 & 29 & 32 & 23 \\
Shannon_H & 3.02 & 2.54 & 3.18 & 2.72 & 2.57 & 2.40 & 2.35 & 2.54 & 2.66 & 2.30 \\
Dominance_D & 0.07 & 0.16 & 0.06 & 0.12 & 0.12 & 0.13 & 0.20 & 0.13 & 0.12 & 0.18 \\
Equitability_J & 0.83 & 0.73 & 0.83 & 0.73 & 0.80 & 0.76 & 0.68 & 0.75 & 0.77 & 0.73 \\
Predators & 41.91 & 74.87 & 38.79 & 61.07 & 46.00 & 44.75 & 31.77 & 59.34 & 63.47 & 34.62 \\
Scrapers & 1.84 & 2.51 & 4.74 & 3.36 & 2.67 & 1.83 & 0.00 & 0.66 & 8.68 & 6.84 \\
Shredders & 12.87 & 4.02 & 17.67 & 5.70 & 30.00 & 3.20 & 2.21 & 0.66 & 2.28 & 0.00 \\
Collectors & 43.38 & 18.59 & 38.79 & 29.87 & 21.33 & 50.23 & 66.02 & 39.44 & 25.57 & 58.55 \\
\hline
\end{tabular}




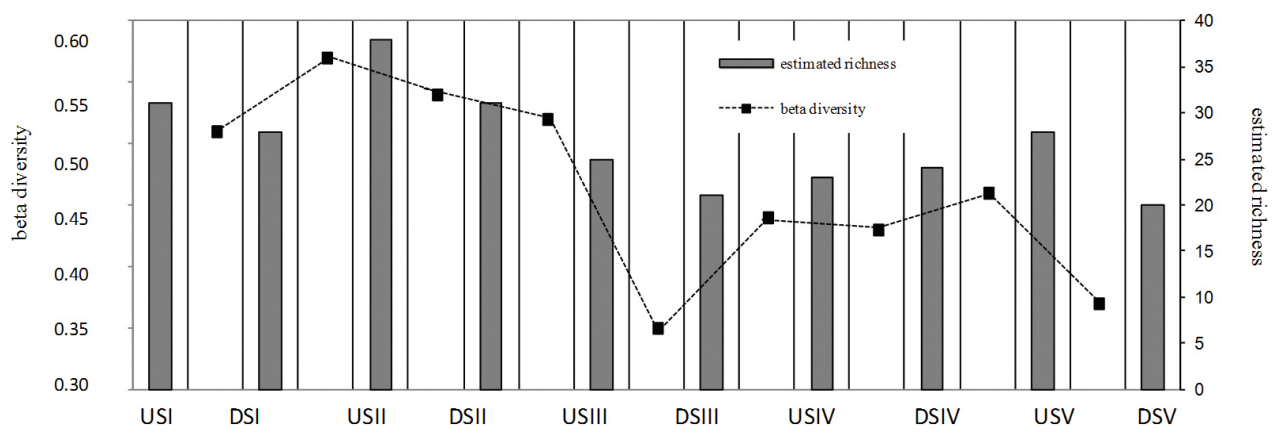

Figure 3. Taxa richness estimated by rarefaction curves and $\beta$ diversity in the upstream and downstream segments of the five dams along the longitudinal profile of the Ribeirão das Anhumas. (Legend as in Figure 1).

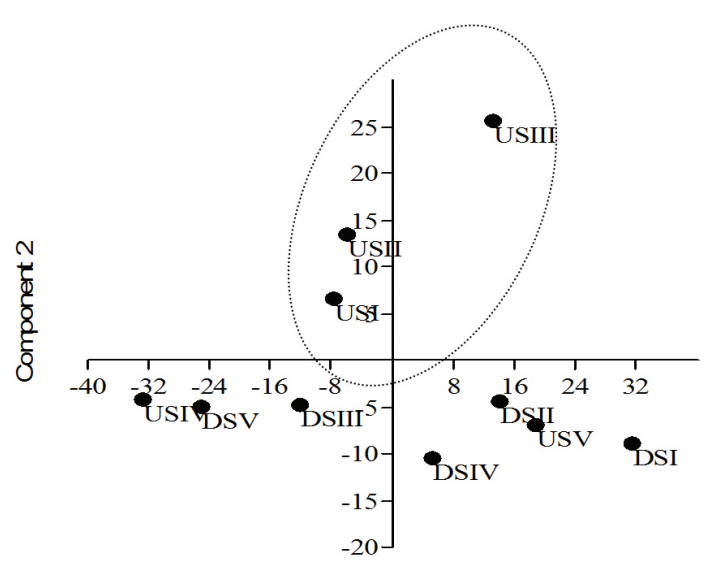

Component 1

Figure 4. PCA analysis for insect functional feeding groups in the upstream and downstream segments of the five dams of the Ribeirão das Anhumas (component $1=74 \%$; component $2=24 \%$ ). The delimited area indicates forested segments with greater contribution of shredder insects. (D) - dam, (US) - upstream, (DS) - downstream.

\section{Conclusions}

There were no significant differences in abundance and richness of aquatic insects between the upstream and downstream segments, indicating that the dams did not influence these variables. As the knowledge of the influence of discontinuity river promoted by dams in Brazil on the aquatic biota are still scarce, further studies are needed to obtain more definitive information about these impacts on aquatic insect community. Differences were observed in the functional feeding groups along the longitudinal profile wherein the participation of shredders and scrapers were present in the segments with preserved riparian vegetation. The higher input of $\mathrm{CPOM}$ arising of the riparian vegetation observed in the forested segments promoted higher heterogeneity of habitat, influencing higher values of Shannon index and $\beta$ diversity for the aquatic insect community of the Ribeirão das Anhumas.

\section{References}

ALBERTONI, EF. and PALMA-SILVA, C., 2006. Macroinvertebrados associados à macrófitas aquáticas flutuantes em canais urbanos de escoamento pluvial (Balneário Cassino, Rio Grande do Sul, RS). Neotropical Biology and Conservation, vol. 1, no. 2, p. 90-100.

BERG, MB., 1995. Larval food and feeding behavior. In ARMITAGE. P., CRANSTON, P.S. and PINDER, LCV. (Eds.). The Chironomidae: the biology and ecology of non-biting midges. London: Chapman \& Hall. p. 140

BISPO, PC. and OLIVEIRA, LG., 2007. Diversity and structure of Ephemeroptera, Plecoptera and Trichoptera (Insecta) assemblages from riffles in mountain streams of Central Brazil. Revista Brasileira de Zoologia, vol. 24, no. 2, p. 283-293. http://dx.doi. org/10.1590/S0101-81752007000200004

BISPO, CP., FROËHLIC, CG. and OLIVEIRA, LG., 2002. Spatial distribution of Plecoptera nymphs in streams of mountanious of central Brazil. Brazilian Journal of Biology, vol. 62, no. 3, p. 409-417. http://dx.doi.org/10.1590/S1519-69842002000300003

BORKENT, A., 1984. The systematic and phylogeny of the Stenochironomus complex (Xestochironomus, Harrisius, and Stenochironomus) (Diptera: Chironomidae). Memoirs of the Entomological Society of Canada, vol. 128, 269 p.

BUSS, DF., BAPTISTA, DF., SILVEIRA, MP., NESSIMIAN, JL. and DORVILLÉ, L.F.M., 2002. Influence of water chemistry and environmental degradation on macroinvertebrate assemblages in a river basin in south-east Brazil. Hydrobiologia, vol. 481, p. 125-136. http://dx.doi.org/10.1023/A:1021281508709

CALLISTO, M., GOULART, M., BARBOSA, F A.R. and ROCHA, O., 2005. Biodiversity assessment of benthic macroinvertebrates along a reservoir cascade in the lower São Francisco River (Northeastern Brazil). Brazilian Journal of Biology, vol. 65, no. 2, p. 229-240. PMid:16097725. http://dx.doi.org/10.1590/ S1519-69842005000200006

CHESSMAN, BC., ROBSON, DP. and KENT, GH., 1987. Changes in the riffle macroinvertebrates fauna of the Tanjil River, Southeast Australia, during construction of Blue Rock Dam. Regulated Rivers: Research \& Management, vol. 1, no. 4, p. 317-329. http://dx.doi.org/10.1002/rrr.3450010404

CORBI, JJ. and TRIVINHO-STRIXINO, S., 2008. Relationship between sugar cane cultivation and stream macroinvertebrate communities: a study developed in the southeast of Brazil. Brazilian Archive of Biology and Technology, vol. 51, no. 4, p. 569-579. http://dx.doi.org/10.1590/S1516-89132008000400015 
COSTA, JM., MACHADO, ABM., LENCIONI, F A.A. and SANTOS, T.C., 2000. Diversidade e distribuição dos ODONATA (Insecta) no Estado de São Paulo, Brasil: Parte I - Lista das espécies e registros bibliográficos. Publicações Avulsas do Museu Nacional, no. 80, p. 1-27.

COVICH, AP., 1988. Geographical and historical comparisons of neotropical streams: biotic diversity and detrital processing in highly variable habitats. Journal of the North American Benthological Society, vol. 7, no. 4, p. 361-386. http://dx.doi. org/10.2307/1467297

DOBSON, M., MATHOOKO, JM., NDEGWA, FK. and M'ERIMBA, C., 2003. Leaf litter processing rates in a Kenyan highland stream, the Njoro River. Hydrobiologia, vol. 519, p. 207-210. http://dx.doi. org/10.1023/B:HYDR.0000026592.50734.ea

DOMÍNGUEZ, E. and FERNÁNDEZ, HR., 2009. Macroinvertebrados bentónicos sudamericanos: sistemática y biología. Tucuman: Fundación Miguel Lillo. p. 411-468.

DOMÍNGUEZ, E., MOLINERI, C., PESCADOR, ML., HUBBARD, MD. and NIETO, C., 2006. Ephemeroptera of South America. Sofia: Pensoft. 646 p. Aquatic biodiversity in Latin America, vol. 2.

DUDGEON, D., 1982. An investigation of physical and biotic processing of two species of leaf litter in Tai Po Kau Forest stream, New Territories, Hong Kong. Archiv für Hydrobiologie, vol. 96 , no. 1, p. 1-32.

-, 2000. The ecology of tropical Asian rivers and streams in relation to biodiversity conservation. Annual Review of Ecology and Systematics, vol. 31, p. 239-263. http://dx.doi.org/10.1146/ annurev.ecolsys.31.1.239

HEINO, J., 2009. Biodiversity of aquatic insects: special gradients and environmental correlates of assemblage-level measures at large scales. Freshwater Reviews, vol. 2, no. 1, p. 1-29.

HULBERT, SH., 1971. The nonconcept of species diversity: a critique and alternative parametres. Ecology, vol. 52, no. 4, p. 577-586. http://dx.doi.org/10.2307/1934145

JANKE, H. and TRIVINHO-STRIXINO, S., 2007. Colonization of leaf litter by aquatic macroinvertebrates: a study in a low order tropical stream. Acta Limnologica Brasiliensia, vol. 19, no. 1, p. 109-115.

JOHNSON, N., REVENGA, C. and ECHEVERRIA, J., 2001. Managing water for people and nature. Science, vol. 292, no. 5519, p. 1071-1072. PMid:11352054. http://dx.doi.org/10.1126/ science. 1058821

LECCI, LS. and FRÖEHLICH, CG., 2007. Plecoptera: Identificação de larvas de Insetos Aquáticos do Estado de São Paulo. Available from: <http://sites.ffclrp.usp.br/aguadoce/guiaonlin>.

MATHURIAU, C. and CHAUVET, E., 2002. Breakdown of leaf litter in aneotropical stream. Journal of the North American Benthological Society, vol. 21, p. 384-396. http://dx.doi.org/10.2307/1468477

MARONEZE, DM., TUPINAMBAS, TH., FRANÇA, JS. and CALLISTO, M., 2011. Effects of flow and spillways on the composition and structure of benthic macroinvertebrates communities in a Brazilian river reach. Brazilian Journal of Biology, vol. 71, no. 3, p. 639-65. PMid:21881787. http://dx.doi. org/10.1590/S1519-69842011000400008

MERRILL, MD., FREEMAN, MC., FREEMAN, BJ., KRAMER, EA. and HARTLE, LM., 2001 Stream loss and fragmentation due to impoundments in the upper Oconee watershed. In Proceedings of the Georgia Water Resource Conference, 2001. University of Georgia. p. 26-27.
MERRITT, RW. and CUMMINS, KW., 1996. An introduction to the aquatic insects of North America. Dubuque: Kendall/Hunt Company., $862 \mathrm{p}$.

MONAGHAN, MT., ROBINSON, CT., SPAAK, P. and WARD, JV., 2005. Macroinvertebrate diversity in fragmented Alpine Stream: implications for freshwater conservation. Aquatic Sciences, vol. 67, p. 454-464. http://dx.doi.org/10.1007/s00027-005-0787-0

NIESER, N. and MELO, AL., 1997. Os heterópteros aquáticos de Minas Gerais: guia introdutório com chave de indentificação para as espécies de Neomorpha; Gerromorpha. Belo Horizonte: Editora UFMG. 180 p.

PARDO, I., CAMPBELL, IC. and BRITTAIN, JE., 1998. Influence of dam operation on mayfly assemblage structure and life histories in two southeastern Australian streams. Regulated Rivers: Research \& Management, vol. 14, p. 285-295. http://dx.doi.org/10.1002/ (SICI)1099-1646(199805/06)14:3<285::AID-RRR502>3.0.CO;2-6

PASSOS, MIS., NESSIMIAN, JL. and DORVILLÉ, LFM., 2003. Distribuição espaço temporal da comunidade de Elmidae (COLEOPTERA) em um rio da floresta da Tijuca, Rio de Janeiro. Boletim do Museu. Nacional, Nova Série Zoologia, vol. 509, p. 1-9.

PEPINELLI, M., 2011. Check list de Simuliidae (Insecta, Diptera) do Estado de São Paulo, Brasil. Biota Neotropica, vol. 11, no. 1A.

PES, AMO., HAMADA, N. and NESSIMIAN, JL., 2005. Chaves de identificação de larvas para família e gêneros de Trichoptera (Insecta) da Amazônia Central, Brasil. Revista Brasileira de Entomologia, vol. 49, no. 2, p. 181-204. http://dx.doi.org/10.1590/ S0085-56262005000200002

RODRIGUES, ASL., 2009. Uma visão holística sobre os ecossistemas fluviais. Revista Biologia, vol. 2, p. 8-11. http://dx.doi.org/10.7594/ revbio.02.02

ROQUE, FR., SIQUEIRA, T. and TRIVINHO-STRIXINO, S., 2005. Ocurrence of Chironomidae larvae living inside fallen-fruits in Atlantic Forest Streams, Brazil. Entomología y Vectores, vol. 12 , no. 2, p. 275-282.

ROQUE, FO. and TRIVINHO-STRIXINO, S., 2001. Benthic macroinvertebrates in mesohabitats of different spatial dimensions in a first orderstream (São Carlos-SP). Acta Limnológica Brasiliensia, vol. 13 , p. 69-77.

-, 2008. Four new species of Endotribelos Grodhaus, a common fallen fruit-dwelling chironomid genus in Brazilian streams (Diptera: Chironomidae: Chironominae). Studies on Neotropical Fauna and Environment, vol., no. 3, p. 191-207.

SANTOS, A., 1999. Distribuição de metais no reservatório de captação de água superficial Anhumas Américo Brasiliense - SP. São Carlos: Universidade de São Paulo. 147 p. Dissertação de Mestrado em Química.

SONG, MY., LEPRIEUR, F., THOMAS, A., LEK-ANG, S., CHON, S. and LEK, S., 2009. Impact of agricultural land use on aquatic insect assemblage in the Garonne river catchment (SW France). Aquatic Ecology, vol. 43, p. 999-1009. http://dx.doi. org/10.1007/s10452-008-9218-3

STRAKA, M., SYROVATKA, V. and HELEŠIC, J., 2012. Temporal and spatial macroinvertebrate variance compared: crucial role of CPOM in a headwater stream. Hydrobiologia, vol. 686, p. 119134. http://dx.doi.org/10.1007/s10750-012-1003-6

SURIANO, MT., 2008. Macroinvertebrados de baixa ordem sob diferentes usos do solo no Estado de São Paulo: subsídios para o biomonitoramento. São Carlos: Universidade Federal de São Carlos. 127 p. Tese de Doutorado em Ecologia e Recursos Naturais. 
TRIVINHO-STRIXINO, S., 2011. Larvas de Chironomidae: guia de identificação. São Carlos: Departamento de Hidrobiologia/ Lab. De Entomologia Aquática, Universidade Federal de São Carlos. 377 p.

TRIVINHO-STRIXINO, S. and STRIXINO, G., 1998. Chironomidae (Diptera) associados a troncos de árvores submersos. Revista Brasileira de Entomologia, vol. 41, p. 173-178.

VINSON, M. and HAWKINS, C., 1998. Biodiversity of stream insect: Variation at local, basin, and regional scales. Annual
Review of Entomology, vol. 43, p. 271-293. PMid:15012391. http://dx.doi.org/10.1146/annurev.ento.43.1.271

WARD, JV. and STANFORD, JA., 1979. Ecological factors controlling stream zoobenthos with emphasis on thermal modification in regulated streams. In WARD, J.V. and STANFORD, JA. (Eds.). The Ecology of Regulated Streams. New York: Plenum Press. p. 35-55.

-, 1983. The serial discontinuity concept of lotic ecosystems. In Fontaine, T.D., Bartell, SM. (Eds.). Dynamics of lotic ecosystems. Ann Arbor Science. p. 29-42. 